\title{
Effect of Irrigation and Fertigation on Gladiolus Crop Water Requirement, Yield and Water Use Efficiency in Chhattisgarh Plain
}

\author{
Usha Yadav*, Narendra Agrawal, PrafullKatre, S. K. Tamrakar and M. P. Tripathi \\ Department of Soil and Water Engineering, IGKV, Raipur Chhattisgarh, India \\ *Corresponding author
}

\section{A B S T R A C T}

\begin{tabular}{|l|}
\hline K e y w or d s \\
Irrigation, \\
Fertigation, Drip, \\
Fertilizers, \\
Gladiolus, \\
Agriculture \\
\hline Article Info \\
\hline $\begin{array}{l}\text { Accepted: } \\
\text { 23 May } 2020 \\
\text { Available Online: } \\
\text { 10 June } 2020\end{array}$ \\
\hline
\end{tabular}

\section{Introduction}

Gladiolus (Gladiolus sp.) is a very popular bulbous ornamental plant. Its magnificent inflorescence with florets of dazzling colors, varying forms and sizes, and long keeping quality makes it an attractive cut flower. Gladiolus spikes can be kept in the vases for 8-10 days depending on the variety and the ambient conditions prevailing in the room. Gladiolus is an essential component of most flower arrangements including bouquets (Agricoop). A cutflower is being grown in an area of 277000 ha in the country with an estimated production of 527000 MT cut flowers and 1.9 MT ha $\mathrm{ha}^{-1}$. Amongst the cut flowers, gladiolus occupied the third position in terms of both area and production.

The major gladiolus producing states in the country are Uttar Pradesh, West Bengal, Odisha, Chhattisgarh, Haryana \& Maharashtra. Gladiolus is also grown in states like Uttarakhand, Karnataka, Andhra Pradesh, and Sikkim. Even though gladiolus is mainly a winter season flower crop, in areas having 
moderate climatic conditions, gladiolus can be grown throughout the year (DAC\&FW2015-16). In Chhattisgarh, the total Area of Flower production is 7130 ha and production 26604 MT and Productivity $3.73 \mathrm{MT} \mathrm{ha}^{-1}$. Out of which the Gladiolus occupies Area of 1346.63 ha and Production 3949.4 MT with Productivity of $2.93 \mathrm{t} \mathrm{ha}^{-1}$. Which is the third rank in production and second rank in the area after tuberose (www.scribed.com).

Flower crops are very much responsive to fertilizer. It is highly capable of exhausting huge nutrients from native soil. So, it requires a higher amount of chemical fertilizer in a balanced proportion for ensuring maximum flower production. Fertilizer requirements of gladiolus like other crops have a vital role in growth, quality, corn, and cormel production. There are some reports on the requirement of Nitrogen (N), Phosphorus (P), Potassium (K), and other fertilization in many countries. Major nutrients like nitrogen, phosphorus, potassium along with zinc noticeably increase the number of flowers, florets/spike, length of the spike, and flowering stem of gladiolus (Halder et al., 2007).

\section{Materials and Methods}

The field experiment was conducted at the Borsi Farm of DauKalyan Singh College of Agriculture and Research Station, Bhatapara (IGKV) Chhattisgarh during the winter season of the year 2018. The experimental site is situated at $21.73^{\circ} \mathrm{N}$ latitude and $81.93^{\circ} \mathrm{E}$ longitude. It has an average elevation of 261 $\mathrm{m}$.

The district Balodabazar-Bhatapara is located at the central part of Chhattisgarh under the Chhattisgarh plain agro-climatic zone. The average rainfall of the district is $1100 \mathrm{~mm}$, the minimum and maximum temperatures are $13.66^{\circ} \mathrm{C}$ to $27.98^{\circ} \mathrm{C}$ respectively. The average relative humidity is $61.43 \%$ and the average wind velocity is $2.08 \mathrm{~m} \mathrm{~s}^{-1}$. The experimental site has sandy loam soil and falls under the semi-arid zone. The properties of the soil such as field capacity, wilting point, bulk density, and soil depth were determined by usual standard methods.

The moisture content was taken at $0.15,0.30$, and $0.45 \mathrm{~m}$ depths of soil in each plot. The experimental field was $5.6 \mathrm{~m}$ long and $43 \mathrm{~m}$ wide. The raised beds of standard size i.e. $5.6 \times 0.6 \mathrm{~m}^{2}$ were prepared for the sowing of Gladiolus. The row-to-row and plant-to-plant spacing were 0.40 and $0.30 \mathrm{~m}$ respectively, 28 no. of the plant were planted in each row.

\section{Drip irrigation system}

The entire experimental drip irrigation system consisted of tube well (water source), pump, control valves, pressure gauge, fertilizer intake assembly, filter, main pipeline, submain line, and laterals. The drippers and lateral spacings were $0.40 \mathrm{~m}$ and $1.2 \mathrm{~m}$, respectively. These investigations were carried out using ten treatments with three replications. Treatments were tested in a randomized block design. The details of the treatments are given below:

\section{Irrigation and fertilizer treatments}

Combinations - $\left(\mathrm{T}_{1}=\mathrm{I}_{1} \mathrm{~F}_{1}, \mathrm{~T}_{2}=\mathrm{I}_{1} \mathrm{~F}_{2}, \mathrm{~T}_{3}=\right.$ $\mathrm{I}_{1} \mathrm{~F}_{3}, \mathrm{~T}_{4}=\mathrm{I}_{2} \mathrm{~F}_{1}, \mathrm{~T}_{5}=\mathrm{I}_{2} \mathrm{~F}_{2}, \mathrm{~T}_{6}=\mathrm{I}_{2} \mathrm{~F}_{3}, \mathrm{~T}_{7}=\mathrm{I}_{3} \mathrm{~F}_{1}$, $\mathrm{T}_{8}=\mathrm{I}_{3} \mathrm{~F}_{2}, \mathrm{~T}_{9}=\mathrm{I}_{3} \mathrm{~F}_{3}$ )

$\mathrm{I}_{1}$ - Irrigation of 0.6 CPE by drip (Cumulative Pan Evaporation)

$\mathrm{I}_{2}$ - Irrigation of $0.8 \mathrm{CPE}$ by drip

$\mathrm{I}_{3}$ - Irrigation of 1.0 CPE by drip

$\mathrm{F}_{1}-80 \%$ RDF (Recommended dose of fertilizer)

$\mathrm{F}_{2}-100 \% \mathrm{RDF}$

$\mathrm{F}_{3}-120 \% \mathrm{RDF}$ 


\section{Control}

$\mathrm{I}_{4}-$ Surface Irrigation at CPE

\section{Water requirement of gladiolus}

Gladiolus corms were sown on 7 November 2017. All treatment plots were irrigated to attain moisture content at field capacity. The amount of water applied during this period was accounted for the total water requirement of the crop. The detailed estimation of the amount of water applied and the time of operation for each treatment is presented in Table 1. Irrigation water was applied at every alternate day based upon cumulative pan evaporation during that period for three irrigation level $\mathrm{I}_{1}, \mathrm{I}_{2}$, and $\mathrm{I}_{3}$. Scheduling of irrigation was done by using crop coefficients in drip irrigation (Doorenbos and Pruitt, 1977) and the same methodology was adopted by Khanam and Patra (2015), Singh et al., (2016) to determine water use by the gladiolus.

The volume of water per bed was calculated by using the following formula.

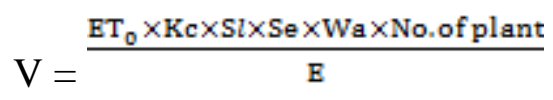

Where, $\mathrm{V}=$ Volume of water $\left(\right.$ lit day ${ }^{-1}$ plant $\left.^{-1}\right), \mathrm{ET}_{0}=$ Reference evapotranspiration $\left(\mathrm{mm} \mathrm{day}^{-1}\right)$,

$\mathrm{K}_{\mathrm{c}}=$ Crop coefficient (as per growth stages), $\mathrm{S}_{l}=$ Spacing between laterals $(\mathrm{m}), \mathrm{S}_{\mathrm{e}}=$ Spacing between emitters $(\mathrm{m}), \mathrm{W}_{\mathrm{a}}=$ Wetted area $(\%), \mathrm{E}=$ Efficiency of system $(\%)$

The operation time of the system (T) was calculated by using the following formula:

$\mathrm{T}=\frac{\mathrm{v}}{\mathrm{q} \times \mathrm{Ne}}$

Where,

$\mathrm{T}=$ Operating time of system (hr), $\mathrm{V}=$ Total volume of water (lit), $q=$ Emitter discharge (lph), $\mathrm{N}_{\mathrm{e}}=$ Number of emitters plot ${ }^{-1}$

\section{Hydraulic performance calculation of drip irrigation}

\section{Uniformity coefficient (UC)}

Uniformity coefficients of emitters were tested using the Christiansen's (1942) formula. It gives the information that how efficiently water is distributed in the field. For determination of the uniformity coefficient of emitter i.e. in-line drip irrigation system, the catch beakers were placed at each selected emission device of selected laterals. The system was operated at pressure $1.2 \mathrm{~kg} \mathrm{~cm}-2$. The water was allowed to the emitter in the beaker for 5 minutes continuously. The volume of water collected in the beaker was measured with the help of a measuring cylinder. The precipitation depth was calculated by dividing the volume of collected water with a cross-sectional area of the beaker.

$\mathrm{CU}={ }^{100\left[1-\frac{\sum x}{M N}\right]}$

Where,

$\mathrm{CU}=$ Uniformity coefficient $(\%), \mathrm{M}=$ Average value of all observations $(\mathrm{mm}), \mathrm{N}=$ Total number of observation points, $\mathrm{X}=$ Absolute deviation of individual observations from the average application rate $(\mathrm{mm})$

\section{Irrigation efficiencies}

\section{Water use efficiency (WUE)}

Water use efficiency (WUE) of gladiolus is computed by dividing the flowering percentage (\%) by total water use (WU, mm) for each treatment. The flowering percentage was computed by dividing the number of gladiolus plant that has flower by the total number of the gladiolus plant in that plot (Aydinsakir et al., 2005). 
$\mathrm{WUE}=\frac{\text { Flowering Percentage }}{\text { Total Wateruse }} \times 100$

Where,

WUE $=$ Water use efficiency $(\%)$

Flowering Percentage(\%)

$=\frac{\text { Flowered plants }}{\text { planted Gladiolus plant }} \times 100$

\section{Fertilizer use efficiency (FUE)}

The fertilizer use efficiency was determined from the yield data and total fertilizer applied. Similar studies were done by Azza et al., (2016) and Solamalai et al., (2005) on gladiolus to study yield and flowering characteristics. Fertilizer use efficiency was computed using the following equation:

FUE $=\frac{\text { Yield of Gladiolus }\left(\mathrm{kg} \mathrm{ha}^{-1}\right)}{\text { Fertilizer applied }\left(\mathrm{kg} \mathrm{ha}^{-1}\right)}$

Where,

$\mathrm{FUE}=$ Fertilizer use efficiency $\left(\mathrm{kgkg}^{-1}\right)$

Economics of drip irrigation system under gladiolus production

The cost of production included the variable cost and fixed cost of the product. The variable cost involved paid out the cost on hired human labour, ploughing, seeds, fertilizers, plant protection, water, supervision, electricity charges, interest on working capital, interest on fixed capital, depreciation, repair, and maintenance charges for installation of drip irrigation system.

The gross monetary returns per hectare were worked out by considering the spike yield from different treatments and prevailing market prices and the net returns were worked out by subtracting the cost of production from gross monetary returns in each treatment.
The benefit: cost ratio was worked out using the formula below:

B:C ratio $=\frac{\text { Net monetary returns }}{\text { Cost of Production }}$

\section{Results and Discussion}

The observations on growth and yield parameters of gladiolus in each treatment were taken to know the effect of different levels of irrigation and fertigation. The results obtained from the study are discussed below:

Among all treatments, the maximum seasonal amount of water $(454.4 \mathrm{~mm})$ was applied in Furrow irrigation followed by level I3 (303.7), I2 (242.96 mm), I1 treatment (182.22 $\mathrm{mm}$ ) respectively from Table 1 . It can be observed that the depths of water applied in November, December, and in February are less as compared to the depth of water applied in January.

\section{Effect of irrigation and fertigation levels on vegetative growth parameters}

Accessibility of the data in the table 3 revealed that the application of irrigation at 0.6 CPE irrigation regime proved its superiority by recording the maximum and significantly higher yield attributes viz, presented in table 3 . The maximum plant height $(76.44 \mathrm{~cm})$, leaves per plant $(8.13)$, no. of shoot per plant (1.29), the diameter of a plant at the base $(1.50 \mathrm{~cm})$ was observed in treatment combination $\mathrm{I}_{1} \mathrm{~F}_{1}$ and the lowest plant height $(69.44 \mathrm{~cm})$, the diameter of a plant at the base $(1.25 \mathrm{~cm})$ was observed in the control (furrow irrigation with $100 \mathrm{RDF}$ ) at the 60 DAP of the crop. The treatment combination $\mathrm{I}_{1} \mathrm{~F}_{1}$ created optimum soil conditions for the growth of Gladiolus and also registered maximum spike yield. From the above results, it is concluded that the plant vegetative growth parameters of Gladiolus increased with the advancement of the age of the crop. 
The plant needed sufficient water from initial to harvesting stages. In the irrigation level, the $\mathrm{I}_{1}$ height of the plant was more due to the supply of sufficient water. The maximum number of leaves helping to cover a large cross-sectional area. Ultimately resulted in enhancing the photosynthesis activity and contributing to higher yield. In the case of irrigation level $\mathrm{I}_{1}(0.6 \mathrm{PE})$, more number of leaves produced per plant which helped to increase the yield. Similar findings were reported by Salma et al., (2013).

\section{Effect of irrigation and fertigation levels on spike yield}

Irrigation and fertigation significantly influenced plant spike initiation, minimum days to spike initiation (70.67), also no. of the spike, as presented in table 4 was observed in treatment combination $\left(\mathrm{I}_{1}=60 \%, \mathrm{~F}_{1}=80 \%\right)$ and the maximum days to spike initiation (76) in control irrigation similarly minimum days to plant colour show (78), flowering (82.67), full bloom (19.33), maximum spike length $(80.12 \mathrm{~cm})$, rachis length $(65 \mathrm{~cm})$, no. of floret (2.67), basal floret (13.08), durability (32) in $I_{1} F_{1}$ and minimum values of the parameter was recorded in control irrigation. This might be because the crop is sensitive to irrigation and it was getting more water than needed for sustainable growth at the different irrigation levels. The number of flower effects on yield of spike per plant. The yield was reduced due to decreasing in the mean fruit weight and a diminished fruit number, (Serrano et al., 1992). The diminished fruit number was reported due to mild water deficits and excessive irrigation. This showed that for the increasing irrigation levels the yield of the crop was decreased. The reduction in yield was found due to water quantities exceeded the proper rates for optimal growth, (Rossi et. al 1988). This result was close to that obtained by Biswas et al., (2015).

\section{Effect of irrigation and fertigation levels on corms and cormel yield}

The maximum number of corm (1.32), weight $(86.81 \mathrm{~g})$, and diameter $(6.66 \mathrm{~cm})$ cormel was recorded in treatment combination $\mathrm{I}_{1} \mathrm{~F}_{1}$ and the minimum number of corm (1.03), weight $(45 \mathrm{~g})$, diameter $(4.2 \mathrm{~cm})$ was recorded in control irrigation, Similarly maximum no. of cormels per plant (80), weight $(30.60 \mathrm{~g})$, and minimum no. of cormel per plant (46), weight (18.20) were recorded in control irrigation. This showed that for the increasing irrigation levels the yield corms and cormels were shown decreasing trend. Similar findings were obtained by Panwar et al., (2016).

\section{Water-saving}

The treatment combinations $\mathrm{I}_{1} \mathrm{~F}_{1}$ is statistically at par, resulting in saving of $60 \%$ irrigation water, likewise, $\mathrm{I}_{2} \mathrm{~F}_{1}$ is statistically at par saving of $45.45 \%$ presented in table 2 and vice versa of flood irrigation $\mathrm{I}_{4}$ was higher than drip irrigation. Water was applied as per irrigation schedules, it was lowest in $\mathrm{I}_{1}$ i.e. 60 $\%$ CPE of water, while it was highest under irrigation schedule $\mathrm{I}_{3}$ i.e. $100 \% \mathrm{CPE}$ of water. Equally findings of Geerish et al., (2017).

\section{Uniformity coefficient}

The maximum uniformity coefficient was $90 \%$ at $1.2 \mathrm{~kg} \mathrm{~cm}^{-2}$ operating pressure in $2 \mathrm{lph}$ emitter discharge. The result falls under the good performance category of the Drip system. This means that the uniform coefficient increases as the operating pressure increases accordingly operating pressure.

At a particular spacing, the average rate of discharge increased as the operating pressure head increased due to constant emission point per unit length of lateral. Hence the uniformity coefficient increased as the operating pressure head increased for all 
emission devices. The results conform to the findings of Popale et al., (2011).

\section{Water use efficiency}

Water use efficiency significantly affected by different irrigation and fertigation level can be seen by figure 1 , observed that the maximum water use efficiency $72.52 \%$ was found in treatment combination $\mathrm{I}_{1} \mathrm{~F}_{1}$ followed by $\mathrm{I}_{1} \mathrm{~F}_{2}$ and $\mathrm{I}_{1} \mathrm{~F}_{3}$ (both $66.64 \%$ ) presented in table 5 . Levels of irrigation and fertigation $T_{2}$ and $T_{3}$, level $\mathrm{T}_{4}, \mathrm{~T}_{5}, \mathrm{~T}_{6}$, and level $\mathrm{T}_{7}, \mathrm{~T}_{8}, \mathrm{~T}_{9}$ are found at par with each other. $\mathrm{T}_{10}$ is significantly different from other treatments, the relationship between treatments and WUE cab be seen by figure 3. It is revealed that the water use efficiency ranged from $22.79 \%$ to $72.52 \%$ under different treatment combinations from the above results it is seen that the individual effect of irrigation (depth) level is very much important and responsible for productive growth of strawberry to get maximum yield and water use efficiency, Ankush et al., (2014). Since the WUE values considered only flowering percentage to compute WUE values, neglecting the effects of other quality characteristics on WUE. Similar findings were observed by Aydinsakir et al., (2005), Thentu et al., (2015) and Biswas et al., (2015).

\section{Fertilizer use efficiency}

The maximum fertilizer use efficiency presented in table 6 i.e. $6.38 \mathrm{~kg} \mathrm{~kg}^{-1}$ was found in treatment combination $\mathrm{I}_{1} \mathrm{~F}_{1}$ and a minimum of $3.68 \mathrm{~kg} \mathrm{~kg}^{-1}$ was observed in control due to very low yields concerning the amount of fertilizer as well as water applied can be seen by figure 2. This result is the conformity of the Agrawal et al., (2018). Similar results were obtained by Kaushal et al., (2012), where they reported that the drip irrigation adoption increases water use efficiency (60-200\%), saves water (20-60\%), reduces fertilization requirement (20-33\%) through fertigation, produces a better quality crop and increases yield (7-25\%) as compared with conventional irrigation.

Table.1 Water applied to gladiolus under different treatments for each month

\begin{tabular}{|c|c|c|c|c|}
\hline Month & & \multicolumn{2}{|c|}{ Depth of Water applied (mm) } & \\
\hline & $0.60 \mathrm{CPE}$ & $0.80 \mathrm{CPE}$ & $1.00 \mathrm{CPE}$ & Control \\
\hline Nov(7-30) & 44.64 & 59.52 & 74.4 & 110.7 \\
\hline December & 53.76 & 71.68 & 89.6 & 134.4 \\
\hline January & 61.44 & 81.92 & 102.4 & 153.6 \\
\hline Feb(1-15) & 22.38 & 29.84 & 37.3 & 55.95 \\
\hline Total & 182.22 & 242.96 & 303.7 & 454.4 \\
\hline
\end{tabular}

Table.2 Total depth of irrigation water applied under different irrigation levels

\begin{tabular}{|r|c|c|c|}
\hline S.No. & Irrigation & $\begin{array}{c}\text { The total depth of water } \\
\text { applied }(\mathbf{c m})\end{array}$ & $\begin{array}{c}\text { Water-saving (\%) Over } \\
\text { control }\end{array}$ \\
\hline 1. & $\mathrm{I}_{1}(0.60 \mathrm{CPE})$ & 18.20 & 60.00 \\
\hline 2. & $\mathrm{I}_{2}(0.80 \mathrm{CPE})$ & 24.3 & 47.2 \\
\hline 3. & $\mathrm{I}_{3}(1.00 \mathrm{CPE})$ & 30.4 & 33 \\
\hline 4. & Control (Furrow) & 45.4 & - \\
\hline
\end{tabular}


Table.3 Effect of different irrigation and fertigation on vegetative growth of gladiolus

\begin{tabular}{|c|c|c|c|c|c|c|c|c|}
\hline Treatment & \multicolumn{2}{|c|}{ Plant height (cm) } & \multicolumn{2}{|c|}{ Number of leaves } & \multicolumn{2}{|c|}{ Number of Shoots } & \multicolumn{2}{c|}{ Girth (cm) } \\
\hline & 30 DAP & 60 DAP & 30 DAP & 60 DAP & 30 DAP & 60 DAP & 30 DAP & 60 DAP \\
\hline $\mathbf{T}_{\mathbf{1}}$ & 55.0 & 76.44 & 5.20 & 8.13 & 1.08 & 1.29 & 1.11 & 1.50 \\
\hline $\mathbf{T}_{\mathbf{2}}$ & 53.33 & 73.61 & 4.96 & 7.36 & 1.05 & 1.21 & 1.05 & 1.42 \\
\hline $\mathbf{T}_{\mathbf{3}}$ & 53.33 & 73.56 & 4.13 & 7.07 & 1.04 & 1.21 & 1.03 & 1.37 \\
\hline $\mathbf{T}_{\mathbf{4}}$ & 54.00 & 74.23 & 5.07 & 7.93 & 1.07 & 1.26 & 1.10 & 1.45 \\
\hline $\mathbf{T}_{\mathbf{5}}$ & 52.67 & 73.06 & 4.07 & 7.07 & 1.03 & 1.15 & 1.00 & 1.35 \\
\hline $\mathbf{T}_{\mathbf{6}}$ & 52.33 & 73.61 & 4.00 & 7.00 & 1.02 & 1.14 & 0.96 & 1.22 \\
\hline $\mathbf{T}_{\mathbf{7}}$ & 53.67 & 74.00 & 5.00 & 7.40 & 1.07 & 1.25 & 1.10 & 1.44 \\
\hline $\mathbf{T}_{\mathbf{8}}$ & 52.17 & 72.56 & 3.90 & 7.00 & 1.00 & 1.14 & 0.95 & 1.20 \\
\hline $\mathbf{T}_{\mathbf{9}}$ & 52.00 & 72.00 & 3.50 & 6.87 & 0.98 & 1.14 & 0.95 & 1.20 \\
\hline $\mathbf{T}_{\mathbf{1 0}}$ & 49.33 & 69.44 & 3.00 & 6.27 & 1.00 & 1.03 & 0.70 & 1.15 \\
\hline $\mathbf{S . E m \pm}$ & 0.861 & 1.27 & 0.390 & 0.279 & 0.336 & 0.037 & 0.061 & 0.017 \\
\hline C.D at 5\% & 1.217 & 3.79 & 1.167 & 0.834 & 1.006 & 0.012 & 0.182 & 0.051 \\
\hline
\end{tabular}

Table.4 Effect of different Irrigation and Fertigation on gladiolus characteristics and yield

\begin{tabular}{|c|c|c|c|c|c|c|c|c|c|c|}
\hline Treatment & $\begin{array}{c}\text { Days } \\
\mathbf{5 0 \%} \\
\text { Spike } \\
\text { Initiation }\end{array}$ & $\begin{array}{c}\text { Days } \\
50 \% \\
\text { Colour } \\
\text { show }\end{array}$ & $\begin{array}{c}\text { Days to } \\
\mathbf{5 0 \%} \\
\text { flowering }\end{array}$ & $\begin{array}{c}\text { Spike } \\
\text { length }(\mathrm{cm})\end{array}$ & $\begin{array}{c}\text { Rachis } \\
\text { Length }(\mathrm{cm})\end{array}$ & $\begin{array}{l}\text { Number of } \\
\text { floret/spike }\end{array}$ & $\begin{array}{c}\text { The } \\
\text { Diameter } \\
\text { of Basal } \\
\text { floret }(\mathrm{cm})\end{array}$ & $\begin{array}{c}\text { Days } \\
\text { to } \\
\text { Full } \\
\text { Bloom }\end{array}$ & Durability & $\begin{array}{c}\text { Days } \\
50 \% \\
\text { Spike } \\
\text { Initiation }\end{array}$ \\
\hline $\mathbf{T}_{1}$ & 70.67 & 78.02 & 82.67 & 80.12 & 65.00 & 22.67 & 13.08 & 19.33 & 32.00 & 70.67 \\
\hline $\mathbf{T}_{2}$ & 74.00 & 81.50 & 83.33 & 79.00 & 63.33 & 20.00 & 12.77 & 20.33 & 31.33 & 74.00 \\
\hline $\mathbf{T}_{3}$ & 74.33 & 81.65 & 83.33 & 78.58 & 62.00 & 19.67 & 12.70 & 20.67 & 31.33 & 74.33 \\
\hline $\mathbf{T}_{4}$ & 73.33 & 81.00 & 83.00 & 80.08 & 64.50 & 22.33 & 12.98 & 20.00 & 31.67 & 73.33 \\
\hline $\mathbf{T}_{5}$ & 74.33 & 82.00 & 83.35 & 75.33 & 62.00 & 19.00 & 12.67 & 21.00 & 31.33 & 74.33 \\
\hline $\mathbf{T}_{6}$ & 75.00 & 82.02 & 84.00 & 75.13 & 61.20 & 18.33 & 12.57 & 21.33 & 31.00 & 75.00 \\
\hline $\mathbf{T}_{7}$ & 73.67 & 81.00 & 83.67 & 79.07 & 63.00 & 22.00 & 12.80 & 20.33 & 31.61 & 73.67 \\
\hline $\mathbf{T}_{8}$ & 75.00 & 82.07 & 84.33 & 73.60 & 60.00 & 18.00 & 12.50 & 21.67 & 30.00 & 75.00 \\
\hline $\mathbf{T}_{9}$ & 76.00 & 82.35 & 84.33 & 71.00 & 59.90 & 17.67 & 12.50 & 21.67 & 30.00 & 76.00 \\
\hline $\mathbf{T}_{10}$ & 77.00 & 83.00 & 84.67 & 69.63 & 59.00 & 17.33 & 11.92 & 22.00 & 29.00 & 77.00 \\
\hline S.Em \pm & 0.612 & 0.378 & 0.095 & 2.312 & 0.068 & 0.341 & 0.016 & 0.106 & 0.027 & 0.612 \\
\hline C.D at $5 \%$ & 1.834 & 1.131 & 0.285 & 6.923 & 0.203 & 1.021 & 0.049 & 0.318 & 0.081 & 1.834 \\
\hline
\end{tabular}


Table.5 Water use efficiency under different treatment combinations

\begin{tabular}{|c|c|c|c|c|c|}
\hline Treatments & $\begin{array}{c}\text { Planted } \\
\text { Gladiolus }\end{array}$ & $\begin{array}{c}\text { Flowered } \\
\text { Gladiolus }\end{array}$ & Flowering (\%) & $\begin{array}{c}\text { Total Water } \\
\text { Use (mm) }\end{array}$ & $\begin{array}{c}\text { WUE } \\
(\mathbf{\%})\end{array}$ \\
\hline $\mathbf{I}_{\mathbf{1}} \mathbf{F}_{\mathbf{1}}$ & 28 & 37.00 & 132 & 182.22 & 72.52 \\
\hline $\mathbf{I}_{\mathbf{1}} \mathbf{F}_{\mathbf{2}}$ & 28 & 34.00 & 121 & 182.22 & 66.64 \\
\hline $\mathbf{I}_{\mathbf{1}} \mathbf{F}_{\mathbf{3}}$ & 28 & 34.00 & 121 & 182.22 & 66.64 \\
\hline $\mathbf{I}_{\mathbf{2}} \mathbf{F}_{\mathbf{1}}$ & 28 & 35.33 & 126 & 242.96 & 51.93 \\
\hline $\mathbf{I}_{\mathbf{2}} \mathbf{F}_{\mathbf{2}}$ & 28 & 32.33 & 115 & 242.96 & 47.52 \\
\hline $\mathbf{I}_{\mathbf{2}} \mathbf{F}_{\mathbf{3}}$ & 28 & 32.00 & 114 & 242.96 & 47.04 \\
\hline $\mathbf{I}_{\mathbf{3}} \mathbf{F}_{\mathbf{1}}$ & 28 & 35.00 & 125 & 303.70 & 41.16 \\
\hline $\mathbf{I}_{\mathbf{3}} \mathbf{F}_{\mathbf{2}}$ & 28 & 32.33 & 115 & 303.70 & 38.02 \\
\hline $\mathbf{I}_{\mathbf{3}} \mathbf{F}_{\mathbf{3}}$ & 28 & 32.00 & 114 & 303.70 & 37.63 \\
\hline $\mathbf{C o n t r o l}$ & 28 & 29.00 & 104 & 454.40 & 22.79 \\
\hline $\mathbf{S . E m} \mathbf{S}$ & & & & & 1.762 \\
\hline $\mathbf{C . D} \mathbf{D} \mathbf{5}$ 5 & & & & & 5.277 \\
\hline
\end{tabular}

Table.6 Fertilizer use efficiency under different treatment combinations

\begin{tabular}{|c|c|c|c|}
\hline Treatments & $\begin{array}{c}\text { Fertilizer } \\
\text { applied }\left(\mathrm{kg} \mathrm{ha}^{-1}\right)\end{array}$ & Spike (kg ha-1) & $\begin{array}{c}\text { Fertilizer use } \\
\text { Efficiency }\left(\mathrm{kg} \mathrm{kg}^{-1}\right)\end{array}$ \\
\hline $\mathrm{I}_{1} \mathrm{~F}_{1}$ & 336 & 2146.07 & 6.38 \\
\hline $\mathrm{I}_{1} \mathrm{~F}_{2}$ & 420 & 2010.46 & 4.78 \\
\hline $\mathrm{I}_{1} \mathrm{~F}_{3}$ & 504 & 1961.14 & 3.89 \\
\hline $\mathrm{I}_{2} \mathrm{~F}_{1}$ & 336 & 2057.43 & 6.12 \\
\hline $\mathrm{I}_{2} \mathrm{~F}_{2}$ & 420 & 1954.91 & 4.65 \\
\hline $\mathrm{I}_{2} \mathrm{~F}_{3}$ & 504 & 1954.64 & 3.87 \\
\hline $\mathrm{I}_{3} \mathrm{~F}_{1}$ & 336 & 2036.79 & 6.06 \\
\hline $\mathrm{I}_{3} \mathrm{~F}_{2}$ & 420 & 1924.40 & 4.58 \\
\hline $\mathrm{I}_{3} \mathrm{~F}_{3}$ & 504 & 1821.03 & 3.61 \\
\hline Control & 420 & 1545.36 & 3.68 \\
\hline
\end{tabular}

Table.7 Cost economics of gladiolus

\begin{tabular}{|c|c|c|c|c|c|c|c|}
\hline $\begin{array}{c}\text { Irrigation } \\
\text { Levels }\end{array}$ & $\begin{array}{c}\text { Spike no. } \\
\text { (Yield ha- }^{-1} \text { ) }\end{array}$ & $\begin{array}{c}\text { Corm no. } \\
\text { (Yield ha }^{-1} \text { ) }\end{array}$ & $\begin{array}{c}\text { Cost of } \\
\text { cultivation } \\
\text { (Rs) }\end{array}$ & $\begin{array}{c}\text { Total Cost } \\
\text { (Rs) }\end{array}$ & $\begin{array}{c}\text { Gross } \\
\text { Returns (Rs) }\end{array}$ & $\begin{array}{c}\text { Net Returns } \\
\text { (Rs) }\end{array}$ & $\begin{array}{c}\text { Benefit- } \\
\text { Cost } \\
\text { Ratio }\end{array}$ \\
\hline $\mathbf{T}_{\mathbf{1}}$ & 1101194 & 110119.4 & 231726.00 & 250691.0 & 880952.2 & 630260.2 & 2.51 \\
\hline $\mathbf{T}_{\mathbf{2}}$ & 101190.7 & 101190.7 & 242427.32 & 261392.2 & 809523.6 & 548130.4 & 2.09 \\
\hline $\mathbf{T}_{\mathbf{3}}$ & 101190.7 & 101190.7 & 253128.69 & 272094.9 & 809523.6 & 537429.7 & 1.97 \\
\hline $\mathbf{T}_{\mathbf{4}}$ & 105148.0 & 105148.0 & 231968.54 & 250934.4 & 841190.0 & 590256.6 & 2.35 \\
\hline $\mathbf{T}_{\mathbf{5}}$ & 96220.23 & 96220.23 & 242669.84 & 261635.4 & 769761.4 & 508126.0 & 1.94 \\
\hline $\mathbf{T}_{\mathbf{6}}$ & 95238.09 & 95238.09 & 253371.21 & 272336.1 & 761904.2 & 489567.1 & 1.81 \\
\hline $\mathbf{T}_{\mathbf{7}}$ & 10166.67 & 104166.67 & 232269.14 & 251234.74 & 833333.36 & 582098.62 & 2.32 \\
\hline $\mathbf{T}_{\mathbf{8}}$ & 96220.23 & 96220.23 & 242970.44 & 261936.04 & 769761.84 & 507825.80 & 1.94 \\
\hline $\mathbf{T}_{\mathbf{9}}$ & 95238.09 & 95238.09 & 253671.81 & 272637.1 & 761904.2 & 489267.1 & 1.80 \\
\hline Control & 86309.52 & 86309.52 & 280300.00 & 280300 & 690476.7 & 410176.7 & 1.46 \\
\hline
\end{tabular}

$($ Cost of cultivation $=$ Fertilizer + Irrigation Water + Labour + Spray material $)$ 


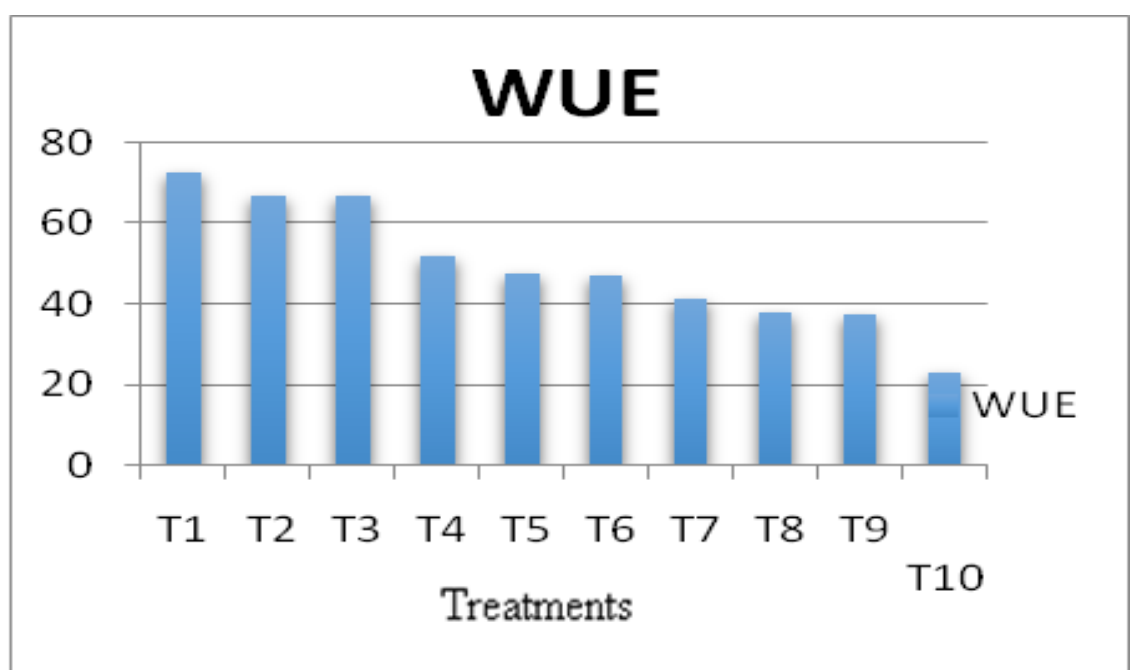

Fig.1 Illustrates the water use efficiency in treatment combinations.

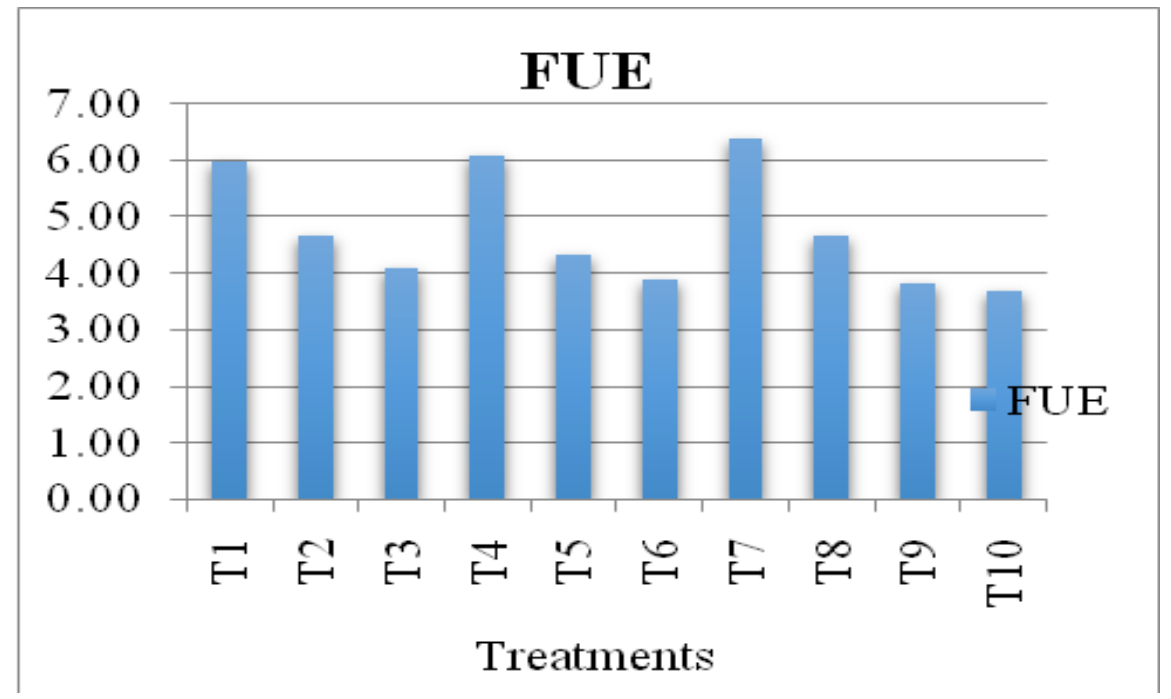

Fig.2 Illustrates the fertilizer use efficiency in all treatment

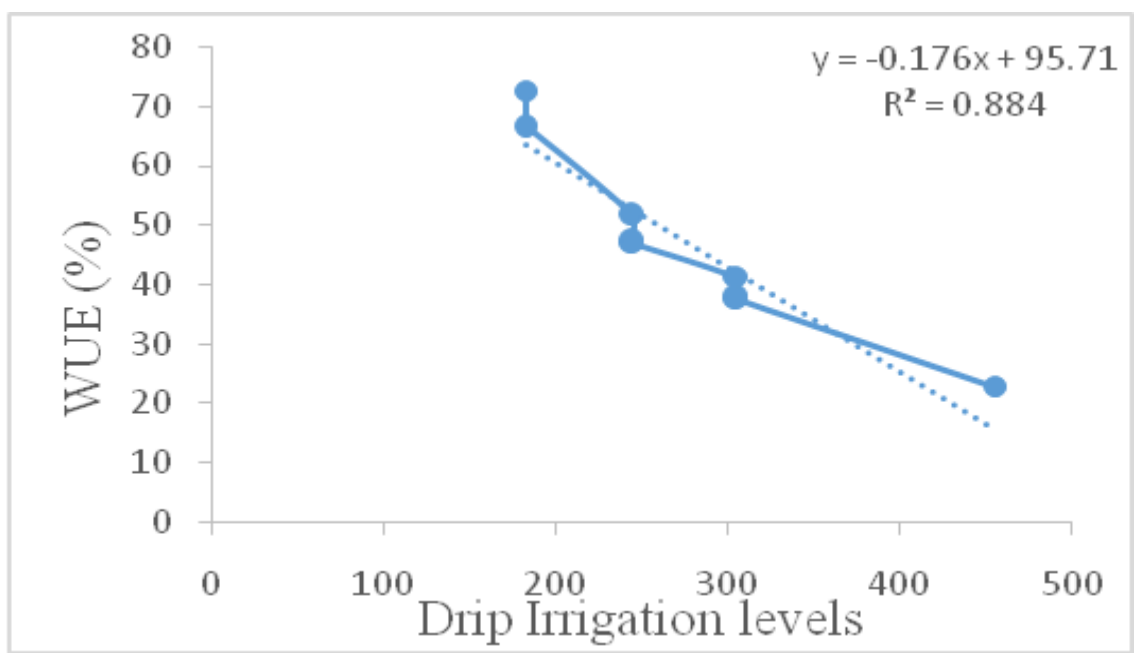

Fig.3 Relation between drip irrigation levels and WUE 


\section{Cost economics for cultivation of gladiolus with drip irrigation system}

Table 7 shows the cost economics of Gladiolus and Maximum net returns of Rs. 630260.72 per ha was obtained under treatment $\mathrm{I}_{1} \mathrm{~F}_{1}$, which is almost 1.50 times more as compared to control (Rs. 410176.17 per ha) methodology used which was adopted by Patil et al., (2010). The benefit-cost ratio was also obtained maximum under $\mathrm{I}_{1} \mathrm{~F}_{1}(2.51)$ and minimum under control (1.46).

The selling price of Gladiolus was taken of Rs.5 per spike because the quality of the produce was good in treatment $\mathrm{I}_{1} \mathrm{~F}_{1}$ as compared to the rest of the treatments. This increase in income may be due to application of water-soluble-fertilizer through the drip system, which could help in a long way for efficient and uniform application of fertilizers with minimum labour involvement to improve the productivity and quality of the produce. The recommended dose of fertilizer through fertigation $(80 \%)$ will minimize the cost of cultivation with an increase in production resulted in a maximum benefit-cost ratio. Similar findings were reported by Gupta et al., (2010), where they concluded that by adopting drip irrigation system, the highest income could be generated in capsicum as against realized under conventional method. The benefit-cost ratio was also noticed maximum with the same treatment combination i.e. $80 \%$ ET through drip $+80 \%$ recommended NPK through fertigation. Presented dada is the conformity of the Biswas et al., (2015).

\section{Acknowledgments}

Authors are thankful to the Head, Department of Soil and Water Engineering, Faculty of Agricultural Engineering, IGKV, Raipur and Dean, DKS College of Agriculture and Research Station, Bhatapara for providing the necessary funds and research related facilities to conduct this research at Borsi Farm, Bhatapara.

\section{References}

Agrawal, N., Tamrakar, S.K., Tripathi, M.P. and Tiwari, R.B. 2018. The Response of Cabbage under Different Levels of Irrigation and Fertigation through Drip. International Journal Current Microbiology Applied Sciences, 6: 750-759.

Ankush, K.O. 2014. Effect of different irrigation levels on growth and yield of strawberry under silver black mulch. B.Tech. Thesis, Engineering College of Agricultural Engineering and Technology Dr. Balasaheb Sawant Konkan Krishi Vidyapeeth, Dapoli415 712, Dist. Ratnagiri, M. S. (INDIA). $120 \mathrm{p}$.

Anonymous. Horticulture Crops 2015-16 (Final), Department of Agriculture Govt. India.www.agricoop.nic.in.

Anonymous. Model Profile of 1.0 acre Gladiolus Cultivation, www. agricoop.nic.in/sites/.../Gladiolus.

Aydinsakir, K., Tuzel, H.I. and Buyuktas, D. (2011). The effects of different irrigation levels on flowering and flower quality of carnation (Dianthus caryophllus L.) irrigated by drip irrigation, African Journal of Biotechnology, 10(66): 14826-14835.

Azza, A. M., Mazhar, and Rawia A. E. (2016). Effect of various doses of chemical fertilizer (Kristal on) individually or in combination with different rates of biofertilizer on growth, flowering, corms yield, and chemical constituents of Gladiolus grandiflorus. International Journal of Pharm Tech Research, 9(12): 139-145.

Biswas, B.C. 2010. Fertigation in High Tech Agriculture A Success Story of A Lady Farmer. Fertiliser Marketing News, 41 (10): 4-8.

Christiansen, J.E. 1942. The uniformity of the application of water by sprinkler systems. Agricultural Engineering, 22: 89-92.

Doorenbos, J., and Pruitt, W.O. (1975). Guidelines for predicting crop water requirements. Irrigation and Drainage. 
Paper No. 24, FAO, Rome, Italy.

Geerish, B. (2017). Studies on Irrigation and Fertigation management on Chili (Capsicum annuum) under the Drip system. M. Tech. Indira Gandhi Krishi Vishwavidlya, Raipur, 107-136.

Gupta, A. J., Ahmed, M.F. and Bhat, F.N. 2010. Studies on yield, quality, water, and fertilizer use efficiency of capsicum under drip irrigation and fertigation, Indian $J$. Horti., 67: 213-218.

Halder, N.K., Rafiuddin, M.D., Siddiky, M.A., Gomes, R and Begam, K.A. (2007). Performance of Gladiolus as influenced by Boron and Zinc. Pakistan Journal of Biological Sciences, 10: 581-585.

Kaushal, A., Patole, R., and Singh, K.G. 2012. Drip irrigation in sugarcane: A review, Agricultural Reviews, 33: 211-219.

Khanam, R. and Patra, R.k. (2015). Effect of Gravity Drip Irrigation on Growth, Yield and Water Use Efficiency of Gladiolus in Lower Gangetic Plain of West Bengal, International Journal of Ecosystem, 5(3A): 132-137.

Michael, A.M., (1997). Irrigation Theory and Practice. Vikas Publishing House Private Limited, New Delhi, p. 489.

Panwar, A. 2016. Effect of organic manures and inorganic fertilizers on growth, flowering, and yield of gladiolus (Gladiolus grandiflorus L.). BSc Thesis, G.B. Pant University of Agriculture \& Technology, Pantnagar, 49-109.

Patil, J.B., Patil, E.R., and Jadhav J.D. 2010. Work out of the cost, return, and profitability of selected flowers in Thane district of Maharashtra. International
Journal of Commerce and Business Management 1: 65-69.

Popale P. G., Bombale, V. T. and Magar, A. P. 2011. Hydraulic Performance of Drip Irrigation System. Engineering and Technology in India 2(1\&2) 24- 28

Rossi, P., Faedi, P., Lucchi, P., and Rosati. P. 1988. The effect of two irrigation volumes on performance on day-neutral strawberry. ActaHorticulturae, 265: 243-250.

Salma, Z., Kumar, S.K., and Ahalawat, P.V. 2013. Effect of mulching and irrigation methods on weed growth and soil moisture percentage in Gladiolus. Bulletin of Environment, Pharmacology, and Life Sciences, 7: 113-118.

Serrano, L., Carbonell, R., Save, O., and Penuelas, O.J. 1992. Effect of irrigation regimes on the yield and water use of strawberry. Irrigation Sciences, 13: 45-48.

Singh, V. K., Tiwari, K.N. and Santosh, D.T. (2016). Estimation of crop coefficient and water requirement of Dutch Roses (Rosa hybrid) under Greenhouse and open field conditions. Irrigation and drainage system engineering, 5: 3.

Solaimalai, A., Baskar, M ., Sadasakthf, A. and Subburamu, K. (2005). Fertigation in HighValue Crops. Tamil Nadu Agricultural University, Vridhachalam. Agricultural Research communication center, 26 (1): 1 13.

Thentu, T.L., Dutta, D., Mudi, D.D. and Saha, A. (2015). Studies on Drip Irrigation and Nitrogen Management in Gladiolus (Gladiolus grandiflorus L.). International Journal of Bio-Resource \& Stress Management, 6(6): 644-650.

\section{How to cite this article:}

Usha Yadav, Narendra Agrawal, PrafullKatre, S. K. Tamrakar and Tripathi, M. P. 2020. Effect of Irrigation and Fertigation on Gladiolus Crop Water Requirement, Yield and Water Use Efficiency in Chhattisgarh Plain. Int.J.Curr.Microbiol.App.Sci. 9(06): 2913-2923. doi: https://doi.org/10.20546/ijcmas.2020.906.351 